\title{
The research of neurospecific proteins and lysosomal peptidehydrolases in frontal neocortex during forming conditioned reaction of active avoiding of rats
}

\author{
A. L. Drozdov, V. I. Chorna ${ }^{1}$, O. S. Koshelev, O. K. Vyatkin \\ Dnipropetrovsk State Medical Academy \\ 9 Dzerzhinsky Street, Dnipropetrovsk, Ukraine, 49044 \\ ${ }^{1}$ National Dnipropetrovsk University \\ 72, Gagarin str., Dnipropetrovsk, Ukraine, 49010
}

v-ch-49a@mail.ru

\begin{abstract}
Dynamics of the activity of neuronal cell adhesion molecule (NCAM) and lysosomal cysteine cathepsins B, $L, H$ was researched in frontal neocortex of rat brain during forming a conditioned reaction of active avoiding. The quantitative estimation of NCAM content in the neocortex membrane fraction was carried on by ELISA in 3, 7, 14 and 21 days after starting animals' training. The dynamics correlation between the NCAM content increasing and cysteine cathepsins activity was obtained, especially for aminopeptidase cathepsin $H$ during the process of memory engram forming in frontal neocortex of rat brain.
\end{abstract}

Keywords: NCAM, cysteine cathepsins, learning, memory.

Introduction. The problem of neurochemical and molecular mechanisms of neurological memory is one of the most urgent tasks of medical and biological investigations [1]. Neurological memory is formed, kept, and reproduced on different levels, starting with molecular, supramolecular, subcelullar ones, and ending with intercellular level, where synapses, neuromediators, hormones, and neurospecific proteins mediate the interaction of neurons $[2,3]$.

One of the types of cell contacts is adhesion interaction, which takes place at the assistance of membrane glycoproteins - molecules of cell adhesion. Neuronal cell adhesion molecule (NCAM) is a neurospecific pro-

(C) Institute of molecular biology and genetics NAS of Ukraine, 2009 tein, providing cell adhesion in interactions of neuron-neuron or neuron-matrix type [4]. NCAM participates in synapse mechanisms, which are the foundation of learning and memory [5]. A significant concentration of this protein was determined in pre- and post-synaptic membranes of neurons, which evidences to its participation in synaptic modifications, caused by neuronal and impulse activity. It is known that learning is based on the processes, related to the increase in the number of synapses and participation of various synaptic and membrane mechanisms of plasticity in the associative process [3]. Due to the activity of extraordinary stimuli, along with destructive processes in the organism there is evident development of proliferative ones, 
depending on a single common factor - the status of lysosomal apparatus of the cell. In both types of processes the key positions are given to lysosomes. They play the role of initiative object and provide control over the progress of destructive disorders in the organism $[1,4]$. The relation of activation of lysosomal apparatus to pathological changes in the organism is common knowledge. It is much harder to determine the role of lysosomes in adaptive-restoring processes, taking place due to extraordinary stimuli. While studying neurochemical and molecular mechanisms of neurological memory, the common practice is to register changes (molecular and/or cytological), capable of remaining for a certain time, which occur in the process of learning, memorizing, and adaptation to any type of influence.

This is an urgent and complicated task, solving which would allow managing adaptive reactions of the organism, including memory [5].

An important role in the formation of long-term memory is given to the exchange of proteins, necessary constituents of which are processes of proteolysis and modification [6]. The lysosomal enzymes are known to participate in degradation of proteins, which come together with axoplasmic flow, with subsequent use of amino acids in the formation of new proteins in the synaptic site directly [7]. About $65-80 \%$ of soluble lysosomal peptidohydrolases are cysteine peptidohydrolases [8], including the most active ones cathepsin B (EC 3.4.22.1), cathepsin L (EC 3.4.22.15), and cathepsin H (EC 3.4.22.19). Their biological functions are related to internal and external cell proteolysis and processing of proteins and peptides. The increase in the level of proteolysis is a sign of neuronal degeneration or dysfunction of brain areas of aged people, e.g. activation of cysteine cathepsin B was determined at Alzheimer's disease $[9,10]$. The study on the features of restricted proteolysis reactions allows understanding the role of cysteine cathepsins in the functioning of a complicated adaptive system of the organism, which includes the processes of forming, keeping, and reproducing mnemonic traces taking into account the significance of specific brain formations, which play the decisive role in them [11].

To enhance the understanding of neurochemical mechanisms of neurological memory, we researched changes in the activity of lysosomal cysteine cathepsins $\mathrm{B}, \mathrm{L}, \mathrm{H}$ and in the content of NCA in the frontal neocortex of rat brain during the formation of conditioned reflex memory.

Materials and Methods. The research was carried out on 79 Wistar line rats, weight 180-230 g. To estimate the dynamics correlation of cathepsins B, L, H activity and the content of neurospecific protein NCAM in the process of forming memory engrams we used the conditioned active avoidance response (CAAR) [3] as a model of mnestic reactions. The selection of this model was caused by the possibility of testing the status of the process of forming memory engrams on each day of learning. Conditioned active-defensive skill was formed in Y-type labyrinth with electrified floor of compartments. The light irritant was selected for conditioned stimulus and nociceptive electrostimulation for unconditioned reinforcement. The training of animals was conducted in six sessions per week with 10 connections of conditioned signal to unconditioned reinforcement until reaching the training criterion of $95 \%$ passing to the lit compartment, which took place before the introduction of nociceptive stimulus. The animals were decapitated in 2 hours after the training sessions. All the operations with brain tissues were conducted at $0-4^{\circ} \mathrm{C}$.

The indices of forming engrams of conditioned reflex memory, NCAM content, and the activity of lysosomal cysteine cathepsins B, L, H in frontal neocortex of control and laboratory rats were analysed after 3, 7,14 , and 21 days of CAAR formation. NCAM content was determined in the membrane fraction of frontal neocortex using ELISA. We used the variant of inhibiting by antigen [12], and showed NCAM concentration in $\mu \mathrm{g} / \mathrm{g}$ of tissue. The free activity of cathepsins B, L, and $\mathrm{H}$ was determined in $10 \%$ solution of homogenates in $0.025 \mathrm{M}$ tris-buffer, $\mathrm{pH} 7.4$, containing $0.15 \mathrm{~m} \mathrm{NaCl}$ and $1 \mathrm{mM}$ EDTA [6]. The activity of cathepsin B was studied by the breaking up of $p$-nitroanilide N, $\alpha$-benzoyl-D,L-arginine (BAPA) (Fluka, Switzerland) [13], the activity of cathepsin L - by hydrolysis of $1 \%$ azocasein, denaturated by $3 \mathrm{M}$ urea [14], and the activity of cathepsin $\mathrm{H}$ - by hydrolysis of 2-naphtylamide L-leucine (Leu-HA, Koch-Light Laboratories, UK) [15].

The specific activity was determined in $1 \mathrm{ml}$ of incubation mixture with preliminary incubation of en- 


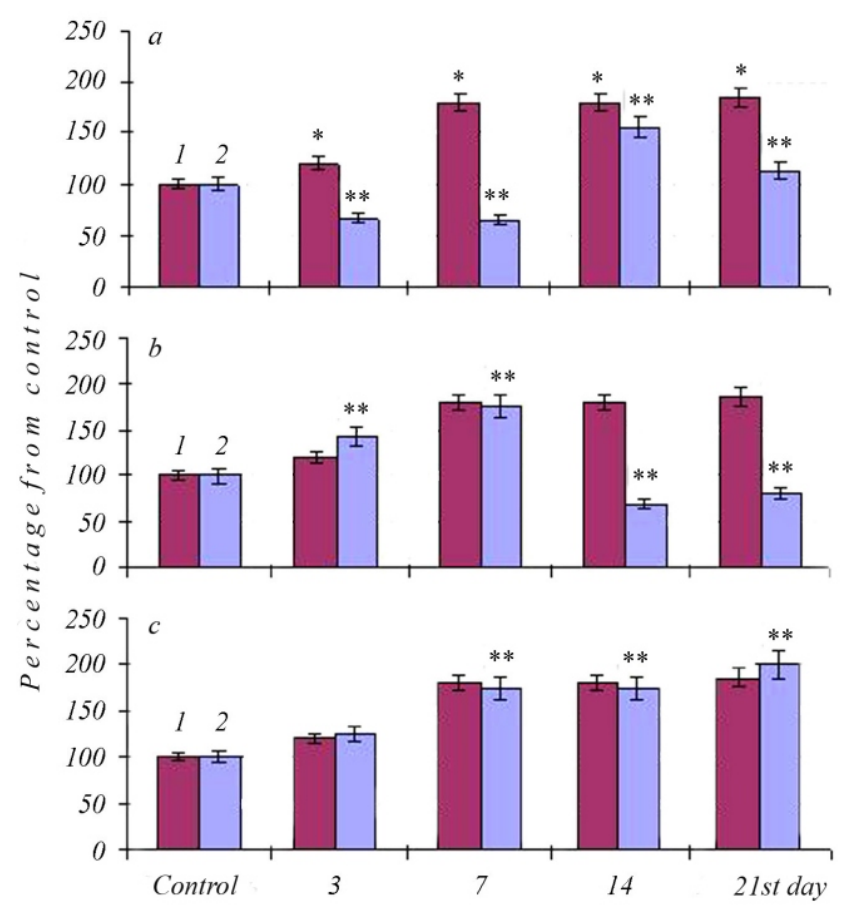

The dynamics of NCAM content and the level of free activity of cysteine cathepsins $\mathrm{B}(a), \mathrm{L}(b), \mathrm{H}(c)$ in the frontal neocortex of rat brain in the process of forming conditioned reflex memory: 1 NCAM $(\mu \mathrm{g} / \mathrm{g}$ of tissue), $\% ; 2(a)-$ cathepsin B ( $\mu$ mol of $p$-nitroaniline per $1 \mathrm{~min}$ per $1 \mathrm{mg}$ of protein), \%; $2(b)-$ cathepsin $\mathrm{L}$ (conventional units per $1 \mathrm{~min}$ per $1 \mathrm{mg}$ of protein), \%; 2 (c) cathepsin $\mathrm{H}$ ( $\mu \mathrm{mol}$ of 2 - naphtylamine per 1 min per $1 \mathrm{mg}$ of protein), $\% ; \mathrm{M} \pm m, n=8 ; * \mathrm{p}$ and $* * \mathrm{p}<0.05$, compared to the control for NCAM and cathepsin, respectively

zymes for $15 \mathrm{~min}$ in the presence of $2 \mathrm{mM}$ of 2-mercapthoethanol and $2 \mathrm{mM} \mathrm{Na}_{2}$-EDTA. The activity was shown using the following substrates: BAPA in $\mu \mathrm{mol}$ of $p$-nitroaniline per $1 \mathrm{~min}$ per $1 \mathrm{mg}$ of protein; Leu-HA - $\mu \mathrm{mol}$ of 2-naphtylamine per $1 \mathrm{~min}$ per $1 \mathrm{mg}$ of protein; azocasein - in conventional units of adsorption at $366 \mathrm{~nm}$ per $1 \mathrm{~min}$ per $1 \mathrm{mg}$ of protein. Bradford's method was used to perform the quantitative estimation of total protein in the samples [16].

Statistical processing of results was performed according to [17].

Results and Discussion. The research proved the correlation between the changes in concentration of the membrane-bound form of NCAM and the free activity of investigated cysteine cathepsins $\mathrm{B}, \mathrm{L}$, and $\mathrm{H}$ in frontal neocortex of rat brain during the formation of conditioned reflex memory.
The specificities of dynamics of the content of neurospecific protein NCAM in the membrane fraction and of the free activity of lysosomal cysteine cathepsins $\mathrm{B}$, L, and $\mathrm{H}$ on the background of changes in neurospecific protein NCAM while forming CAAR are presented in Figure ( $a, b, c$, respectively).

The specificity of dynamics of the activity of cathepsin B was its probable decrease by 33 and $35 \%$ (p $<0.05$ ) on the $3^{\text {rd }}$ and $7^{\text {th }}$ days of training (Figure, $a$ ) and its increase by $57 \%$ on the $14^{\text {th }}$ day, compared to the control. The tendency to increasing the activity of cathepsin B compared to the control was observed on the $21^{\text {st }}$ day of forming CAAR. It is noteworthy that the increase in free activity of lysosomal cysteine cathepsins is an early sensitive sign of changes in the stability of lysosomes membranes [6]. The analysis of the change in NCAM concentration testifies to probable increase in the content of investigated neurospecific protein on the $3^{\text {rd }}$ day of training. It is the $3^{\text {rd }}$ day after the beginning of the experiment, when there are much fewer mistakes of animals in passing to the dark compartment of the labyrinth, at the same time there are much more reactions of active escape from the nociceptive irritant. During the following stage $\left(7^{\text {th }}-21^{\text {st }}\right.$ days $)$ of forming the conditioned active-defensive skill of rats, the NCAM concentration in the membrane fractions of neocortex increases by about $86 \%$ with maximal content on the $21^{\text {st }}$ day of training, ending the formation of stable conditioned reflex memory. It may evidence to enforcement of memory engrams and possible coding of information into long-term memory. Learning and memory are important features of variability and plasticity of the nervous system [13]. There is evident correlation between the increase in expression and concentration of neurospecific proteins and the stages of memory formation.

The dynamics of cathepsin L activity and NCAM content at the formation of conditioned reflex memory of rats is presented in Figure, $b$. It demonstrates the increase in the level of free activity of cathepsin L by 43 and $77 \%$ after 3 and 7 days of CAAR formation, respectively, and the decrease by 30 and $28 \%$ on the $14^{\text {th }}$ and $21^{\text {st }}$ days of observation, respectively.

The changes in the level of cathepsin $\mathrm{H}$ activity and NCAM concentration in the frontal neocortex while forming engrams of conditioned reflex memory are pre- 
sented in Figure, $c$. It was determined that there is a reliable increase in the level of free activity of lysosome cysteine aminopeptidase (cathepsin $\mathrm{H}$ ) at the increase of expression of the neurospecific protein, starting on the $3^{\text {rd }}$ day of CAAR formation. Free activity of cathepsin $\mathrm{H}$ increases by $75 \%$ on the $7^{\text {th }}$ and $14^{\text {th }}$ days of training, compared to the control. Our observations are in good agreement with the data on significant reactivity of lysosomes of nervous tissue cells, cells of neocortex of brain, in particular, regarding the formation of mnemonic traces. The highest level of activity of cathepsin $\mathrm{H}$ in the frontal neocortex of rat brain was registered on the $21^{\text {st }}$ day of forming conditioned reflex memory with similar changes in the dynamics of NCAM concentration. The data presented evidence to the fact that lysosomal cysteine proteases - cathepsins $\mathrm{B}, \mathrm{L}$, and $\mathrm{H}$ - are intensively reacting to the process of CAAR formation, taking place in brain tissues and participating in adaptive reorganization of protein metabolism. This process may be based on the decrease in the stability of lysosome membranes, which results in the increase in the level of free activity of cathepsins in the brain cortex of laboratory rats.

Conclusions. Therefore, the determined specificities of the dynamics of the content of NCAM, participating in the regulation of the processes of synaptic re-modelling and, according to Yamagata et al. [18], capable of launching synaptic plasticity and maturing of synapse structure, testify to the fact that the reliable increase in NCAM concentration has impact on the processes of plastic re-organization of synaptic connections in the frontal neocortex of rat brain, starting on the $3^{\text {rd }}$ day of CAAR formation. The dynamics of the levels of free activity of lysosomal cysteine cathepsins on the background of changes in the NCAM content in the frontal neocortex of rat brain, where active-defensive skill was formed, evidences to their physiological and neurochemical role in the processes of learning and CAAR formation.

\section{О. Л. Дроздов, В. І. Чорна, О. С. Кошелєв , О. К. Вяткін}

Дослідження нейроспецифічних білків та лізосомних протеаз фронтальної зони неокортексу при формуванні умовної реакції активного уникнення у щурів

Резюме
Досліджено зміни концентрації нейрональної молекули клітинної адгезії (NCAM) і динаміку активності лізосомних ичстеїнових катепсинів $B, L$ i H y фронтальній зоні неокортексу головного мозку щурів при виробленні умовної реакції активного уникнення. Кількісну оцінку вмісту NCAM у мембранній фракиії неокортексу здійснено методом твердофазного імуноферментного аналізу. Дослідження проводили через 3, 7, 14 i 21 добу після початку навчання. Визначено підвищення вмісту NCAM і рівнів активности цистеїнових катепсинів (особливо амінопептидази - катепсину Н) у процесі формування енграм пам'яті.

Ключові слова: NCAM, ичистеїнові катепсини, навчання, пам'ять.

А. Л. Дроздов, В. И. Черная, О. С. Комелев, О. К. Вяткин

Исследование нейроспецифических белков и лизосомных протеаз фронтальной зоны неокортекса при формировании условной реакции активного избегания у крыс

Резюме

Исследованы изменения конщентрации нейрональной молекуль клеточной адгезии (NCAM) и активности лизосомных ичистеиновых катепсинов $B, L$ и Н во фронтальной зоне неокортекса головного мозга крыс при формировании навыка условной реакиии активного избегания. Количественную оиенку содержания NCAM в мембранной фракиии неокортекса проводили методом твердофазного иммуноферментного анализа через 3, 7, 14 и 21 сутки после начала обучения животных. Установлено повыцение концентрации NCAM и уровней активности ицстеиновых катепсинов (особенно аминопептидазы - катепсина H) в прочессе формирования энграмм памяти.

Ключевые слова: NCAM, иистеиновые катепсины, обучение, память.

\section{REFERENCES}

1. Ashmarin I. P. Neyrochimiya.-M.: Izd-vo In-ta biomed. chimii RAMN, 1996.-470 s.

2. Nakanishi H. Microglial functions and proteases // Mol. Neurobiol.-2003.-27, N 2.-P. 163-176.

3. Kruglikov R. I. Neyrochimicheskie mechanizmy obucheniya i pamyati.-M.: Nauka, 1981.-211 s.

4. Sakisaka T., Takaj Y. Cell adhesion molecules in CNS // J. Cell Sci.-2005.-118, N 23.-P. 5407-5410.

5. Washbourne P., Dityatev A., Sxheiffele P., Biderer T. Cell adhesion molecules in synapse formation // J. Neurosci.2004.-42.-P. 9244-9249.

6. Stoka $V$., Turk B., Turk V. Lysosomal cystein proteases: structural features and their role in apoptosis // IUBMB Life.2005.-57, N 4-5.-P. 347-353.

7. Derkachev $V$. $V$. Molekulyarnye i kletochnye mechanizmy pamyati.-M.: Medizina, 1977.-256 s.

8. Artal-Sanz P., Tavernakis $N$. Proteolytic mechanisms in neurotic cell death and neurodegeneration // FEBS Lett.-2005.579.-P. 3287-3296.

9. Guicciardi M., Leist M., Gores G. Lysosomes in cell death // Oncogene.-2004.-23.-P. 2881-2890. 
10. Nakamishi H., Neuronal and microglial cathepsins in aging and age-related diseases // Ageing Res. Rev.-2003.-2.P. 367-381.

11. Mohamed M. M., Sloane B. Cysteine cathepsins: Multifunctional enzymes in cancer // Nature.-2006.-6.-P. 764-775.

12. Ibsen S., Beresin V., Norgoard-Pedersen B., Bock E. Enzyme linked immunosorbent assay of D2-glycoprotein // J. Neurochem.-1983.-N 4.-P. 356-362.

13. Barrett A. J., Kirscke H. Cathepsin B, cathepsin H and cathepsin L // Meth. Enzymol.-1981.-80.-P. 535-561.

14. Berezin V. A., Chornaya V. I., Reva A. D., Smagina L. D. Purification and some properties of thiol-activated cathepsin from bovine cerebral hemispheres and cerebellum // The Ukr. Biochem. J.-1982.-54, N 3.-P. 249-253.
15. Chornaya V. I., Reva A. D. Cathepsin H activity in the human brain and head tumours // The Ukr. Biochem. J.-1989.-61, N 5.-P. 47-50.

16. Bradford M. M. A rapid and sensitive method for the quantitation of microgram quantities of protein utilizing the principle of protein-dye binding. // Anal. Biochem.-1976.72.-P. 248-250.

17. Lakin G. F. Biometriya.-M.: Vyssh. shk., 1990.-352 s.

18. Yamagata M., Weiner J., Sanes J. Synaptic adhesion molecules // Mol. Neurobiol.-2003.-N 23.-P. 167-176.

UDC 577:112.8:576.311.34:612.821.2-092.9 Received 03.03.08 